\title{
Methods for Alkaline Recovery of Aluminum from Bauxite Residue
}

\author{
Frank M. Kaußen ${ }^{1} \cdot$ Bernd Friedrich $^{1}$
}

Published online: 5 May 2016

(C) The Minerals, Metals \& Materials Society (TMS) 2016

\begin{abstract}
Different ways for alkaline recovery of aluminum from bauxite residue are considered from the literature and examined in experiments. The advantages and disadvantages of a high-temperature digestion via Bayer process and soda-lime sintering process are elaborated and compared. As a hybrid process, bauxite residue undergoes a reductive smelting process with lime addition in an electric arc furnace in order to generate aluminaenriched slag. This slag is subsequently treated with highpressure caustic leaching at moderated (200-300 g/l) and high (572-762 g/l) sodium hydroxide concentrations. The aluminum extractions are related to phase transitions in mineralogy caused by the process parameter and are analyzed and proofed by x-ray diffraction. The results show moderate aluminum recoveries of $70 \%$ in case of the use of Bayer process, extremely high aluminum extractions of $95 \%$ in case of slag leaching at high $\mathrm{NaOH}$ concentrations, and even high recoveries of almost $90 \%$ achieved by an optimized sinter process with subsequent leaching at $50{ }^{\circ} \mathrm{C}$ with water. Special focus throughout all experiments is set on the dissolution of silicon as major impurity in the leachate.
\end{abstract}

Keywords Bauxite residue $\cdot$ Red mud $\cdot$ Aluminum extraction $\cdot$ Aluminum recovery $\cdot$ Sodium carbonate sintering $\cdot$ Bayer process

The contributing editor for this article was Yiannis Pontikes.

Frank M. Kaußen

fkaussen@ime-aachen.de

1 IME Department of Process Metallurgy and Metal Recycling, RWTH Aachen University, Intzestraße 3, 52056 Aachen, Germany

\section{Introduction}

Although aluminum is one of the most abundant metals in earth's crust, its first isolation was succeeded in 1825 by Christian Ørsted who firstly gained anhydrous aluminum chloride [1]. Since aluminum is an ignoble metal with a very low standard potential $\left(\mathrm{Al}^{3+}+3 \mathrm{e}^{-} 己 \mathrm{Al}\right)$ of $-1676 \mathrm{~V}$ [2] and a high oxygen affinity (free Gibbs energy $2 \mathrm{Al}+2 /$ $3 \mathrm{O}_{2} \rightleftharpoons \mathrm{Al}_{2} \mathrm{O}_{3}$ of $-1582,207 \mathrm{~kJ} / \mathrm{mol}$ [3]), an elaborated separation of accompanying elements in raw material (refining step) must be completed prior to the generation of metallic aluminum (reduction step). Therefore, it is a major issue to create to separation as selective as possible. Hereinafter, three processes for the treatment of aluminumbearing materials like bauxite and bauxite residue are exemplarily shown and experimentally verified by the benchmark of aluminum recovery and selectivity regarding silicon.

\section{Bayer Process}

A massive price drop in production of aluminum, which led finally to the breakthrough of this light metal in industrial applications, was achieved with the invention of the socalled Bayer process in 1887 with its first commercial implementation in 1893. Today more than $95 \%$ of the worldwide produced alumina, which is also the intermediate for the production of aluminum metal, is processed by the Bayer process [4]. This process is based on the alkaline leaching of aluminum-bearing ores (mostly bauxite) with sodium hydroxide solution. At this high $\mathrm{pH}$ value and elevated temperature and pressure, aluminum hydroxides from bauxite dissolve selectively as following Eq. 1 (in this case gibbsite), while most of the other compounds remain insoluble in the leaching or bauxite residue, the so-called 
red mud. In this step, the entire refining is completed and aluminum is separated from accompanying elements.

$$
\mathrm{Al}(\mathrm{OH})_{3(\mathrm{~s})}+\mathrm{NaOH}_{(\mathrm{aq})} \rightleftharpoons \mathrm{Al}(\mathrm{OH})_{4(\mathrm{aq})}^{-}+\mathrm{Na}_{(\mathrm{aq})}^{+}
$$

To force reaction 1, elevated or even high temperatures are necessary depending on the mineralogy of the processed bauxite. The main aluminum phases in bauxite are trihydrates like gibbsite (also known as hydrargillite) or monohydrates like boehmite and diaspore. While trihydrates are better soluble at temperatures of about $135-150^{\circ}$ $\mathrm{C}$, boehmite is treated at temperatures of $205-245{ }^{\circ} \mathrm{C}$ and diaspore needs the highest digestion temperatures above $250{ }^{\circ} \mathrm{C}$ [5]. Due to their mineral composition, bauxites can be divided into two groups: karst bauxites and lateritic bauxites. Lateritic bauxites are weathered minerals containing mostly gibbsite with only small amounts of boehmite and are typical for tropical deposits. Karst bauxites contain boehmite accompanied with small amounts of diaspore [6]. They can be found for instance in Europe. After digestion, the supersaturated liquor is cooled down and the addition of nucleation agents leads to $\mathrm{Al}$ $(\mathrm{OH})_{3}$ crystallization and to an inversion of reaction 1 . The released caustic soda can be recycled for the bauxite digestion.

Generally, silica is insoluble in caustic solutions. The exposition to weather turns silicates, e.g., minerals of the feldspar group, partly into clay minerals like kaolinite which dissolves according to Eq. 2. Moreover, at highdigestion temperatures, quartz is also attacked by caustic soda. The dissolved silica is not stable and precipitates immediately due to the reaction with caustic soda and dissolved aluminum as shown in Eq. 3. [5-7]

$$
\begin{aligned}
& \mathrm{Al}_{2} \mathrm{O}_{3} \cdot \mathrm{SiO}_{2} \cdot 2 \mathrm{H}_{2} \mathrm{O}_{(\mathrm{s})}+6 \mathrm{NaOH}_{(\mathrm{aq})} \rightleftharpoons 2 \mathrm{Na}_{2} \mathrm{SiO}_{3(\mathrm{aq})} \\
& \quad+2 \mathrm{NaAlO}_{2(\mathrm{aq})}+5 \mathrm{H}_{2} \mathrm{O}_{(\mathrm{l})} \\
& 6 \mathrm{Na}_{2} \mathrm{SiO}_{3(\mathrm{aq})}+6 \mathrm{NaAlO}_{2(\mathrm{aq})}+\mathrm{Na}_{2} \mathrm{X}_{(\mathrm{aq})}+12 \mathrm{H}_{2} \mathrm{O}_{(\mathrm{l})} \rightleftharpoons \\
& 3\left(\mathrm{Na}_{2} \mathrm{O} \cdot \mathrm{Al}_{2} \mathrm{O}_{3} \cdot 2 \mathrm{SiO}_{2} \cdot n \mathrm{H}_{2} \mathrm{O}\right) \cdot \mathrm{Na}_{2} \mathrm{X}_{(\mathrm{s})}+12 \mathrm{NaOH}_{(\mathrm{aq})} \\
& \mathrm{X}: \text { anions like } \mathrm{CO}_{3}^{2-}, \mathrm{SO}_{4}^{2-}, \mathrm{AlO}_{2}^{-}, 2 \mathrm{OH}^{-}, 2 \mathrm{Cl}^{-} .
\end{aligned}
$$

The formed products are sodalite, as shown in reaction 3, as an intermediate product and cancrinite as the thermodynamically stable final product [8]. Especially, Barnes [9-11] examined the kinetics and reaction mechanism of sodalite and cancrinite precipitation and found that firstly sodalite is precipitated as the rate-determining step, and afterward at elevated temperatures, cancrinite with its lower solubility at equilibrium is formed by dissolving and rearranging of sodalite compounds. Nevertheless both compounds leave the process together with the other insoluble compounds as red mud and cause a considerable loss of aluminum.
Overall, the Bayer process is an economic and productive circular process for selective separation of aluminum hydroxide. Nevertheless, the formation of sodium aluminum silicates lowers the aluminum recovery. Commonly used bauxites contain 30-60 wt $\% \mathrm{Al}_{2} \mathrm{O}_{3}[4,6]$, and afterward the deposited red mud still contains aluminum amounts of $10-25 \mathrm{wt} \% \mathrm{Al}_{2} \mathrm{O}_{3}$ [12].

\section{Soda Sintering Process}

The soda sintering process is used for materials which are hardly digestible via the Bayer process and requires high temperatures of $800-1200{ }^{\circ} \mathrm{C}$, usually $1000-1200{ }^{\circ} \mathrm{C}[13-$ 17]. It is basically a "dry digestion" of aluminum oxides with soda $\left(\mathrm{Na}_{2} \mathrm{CO}_{3}\right)$ and employs the principle of the sodapot-ash digestion, but in this case without the use of $\mathrm{K}_{2} \mathrm{CO}_{3}$. The reaction mechanisms are shown in Eqs. 4 and 5 for trivalent metals (M) like aluminum or iron [18] and in Eq. 6 for tetravalent metals (M) like silicon or titanium [17]. It becomes obvious that either alumina caused by the calcination of aluminum hydroxides is turned into watersoluble sodium aluminate or alumina strongly bound in aluminosilicates is transferred into water-soluble sodium aluminate as well, while the silica reacts to even watersoluble sodium silicate. Sodium ferrite reacts with water to iron(III)hydroxide and caustic soda [19].

$$
\begin{aligned}
& \mathrm{M}_{2} \mathrm{O}_{3(\mathrm{~s})}+\mathrm{Na}_{2} \mathrm{CO}_{3(\mathrm{~s})} \rightleftharpoons 2 \mathrm{NaMO}_{2(\mathrm{~s})}+\mathrm{CO}_{2(\mathrm{~g})} \\
& \mathrm{M}=\text { trivalent metal }(\mathrm{Al}, \mathrm{Fe}, \text { etc. }) \\
& \mathrm{M}_{2} \mathrm{SiO}_{5(\mathrm{~s})}+3 \mathrm{Na}_{2} \mathrm{CO}_{3(\mathrm{~s})} \rightleftharpoons 2 \mathrm{NaMO}_{2(\mathrm{~s})}+3 \mathrm{CO}_{2(\mathrm{~g})} \\
& \quad+\mathrm{Na}_{4} \mathrm{SiO}_{4(\mathrm{~s})}
\end{aligned}
$$

The by-product sodium titanate is insoluble in water and does not influence the subsequent leaching step but causes soda losses.

$$
\begin{gathered}
\mathrm{MO}_{2(\mathrm{~s})}+\mathrm{Na}_{2} \mathrm{CO}_{3(\mathrm{~s})} \rightleftharpoons \mathrm{Na}_{2} \mathrm{MO}_{3(\mathrm{~s})}+\mathrm{CO}_{2(\mathrm{~g})} \\
\mathrm{M}=\text { tetravalent metal }(\mathrm{Si}, \mathrm{Ti}, \text { etc. })
\end{gathered}
$$

Unfortunately, hazardous elements like arsenic or hexavalent chromium are bound in water-soluble species like $\mathrm{NaAsO}_{2}$ and $\mathrm{Na}_{2} \mathrm{CrO}_{4}$ as well. Moreover, also sodium silicate $\left(\mathrm{Na}_{2} \mathrm{SiO}_{3}\right)$ is water-soluble and leads to the contamination of the leachate.

Since the reaction product of all reactions (4-6) is always carbon dioxide, the reactions can be pushed toward the formation of the desired product sodium aluminate by lowering the carbon dioxide partial pressure. This can be either achieved by frequent exchange of atmosphere or by the addition of carbon. At sintering temperatures around $1000^{\circ}$ $\mathrm{C}$, carbon dioxide is split into carbon monoxide, according to the Boudouard reaction, as shown in reaction 7. $[14,16]$ 
$\mathrm{CO}_{2(\mathrm{~g})}+\mathrm{C}_{(\mathrm{s})} \rightleftharpoons 2 \mathrm{CO}_{(\mathrm{g})}$

The addition of carbon can also be used for a simultaneous carbothermic reduction of hematite to magnetite or even metallic iron. The reaction takes either place as direct reduction (reactions 8, 10) or by carbon monoxide according to reactions 9 and 11. [16]

$$
\begin{aligned}
& 3 \mathrm{Fe}_{2} \mathrm{O}_{3(\mathrm{~s})}+\mathrm{C}_{(\mathrm{s})} \rightleftharpoons 2 \mathrm{Fe}_{3} \mathrm{O}_{4(\mathrm{~s})}+\mathrm{CO}_{(\mathrm{g})} \\
& 3 \mathrm{Fe}_{2} \mathrm{O}_{3(\mathrm{~s})}+\mathrm{CO}_{(\mathrm{g})} \rightleftharpoons 2 \mathrm{Fe}_{3} \mathrm{O}_{4(\mathrm{~s})}+\mathrm{CO}_{2(\mathrm{~g})} \\
& \mathrm{Fe}_{2} \mathrm{O}_{3(\mathrm{~s})}+3 \mathrm{C}_{(\mathrm{s})} \rightleftharpoons 2 \mathrm{Fe}_{(\mathrm{s})}+3 \mathrm{CO}_{(\mathrm{g})} \\
& \mathrm{Fe}_{2} \mathrm{O}_{3(\mathrm{~s})}+3 \mathrm{CO}_{(\mathrm{g})} \rightleftharpoons 2 \mathrm{Fe}_{(\mathrm{s})}+3 \mathrm{CO}_{2(\mathrm{~g})}
\end{aligned}
$$

After sinter crushing, the formed magnetic phases magnetite or iron can be extracted by magnetic separation. This process reduces the mass flow in the subsequent leaching step, minimizes losses of wash-water after filtration, and produces a high iron-containing intermediate product, attractive for the iron industry. Nevertheless the iron recoveries by magnetic separation of magnetite are in the range of 50-60\% [16, 20] and rather improvable. For a complete reduction to metallic iron, the iron recoveries are better and reach values of $>80 \%$, but require higher carbon additions. The idea of iron reduction was predominantly driven by the minimization of the soda additions due to the avoidance of the formation of sodium ferrite. Already in 1975, Hrishikesan [14] found out that the reduction of hematite in combination with magnetic separation does not improve the aluminum yield or further reduce the soda need. Therefore, he comes to the conclusion that the process can waive a magnetic separation in order to save operating and equipment costs. Moreover, it has to be taken into account that aluminum losses also occur due to misssorting and entrapments of aluminum-bearing phases in the magnetic fraction. The magnetic separation can be done even after leaching, but in contact with water the formed iron would re-oxidize to magnetite which means that the complete reduction to metallic iron accompanied by higher demand of reduction agents would be futile.

Moreover, the input material must be crushed, dried, and blended with additives. The produced sinter must be crushed and ground again meaning additional effort and preparation for the subsequent leaching step. Therefore, it might be suitable to create a self-disintegrating sinter in order to avoid at least the energy consuming crushing step. The mechanism is based on the phase transformation of dicalcium silicate (see Eq. 12) from its monoclinic into orthorhombic structure during cooling which results in a molar volume expansion of $10 \%$. Since $\mathrm{Ca}_{2} \mathrm{SiO}_{4}$ is the preferred phase in order to bind silica, it is theoretically not necessary to add extra amounts of lime just in order to reach the composition for self-disintegrating sinter [21].
Nevertheless, the sintering process is due to the required high temperatures very expensive but for instance in China, the process is still in operation. Furthermore, the simultaneous separation and winning of an iron-rich concentrate for the iron industry may improve the economic efficiency of the sinter process.

\section{Addition of Lime to Avoid Silicon Contamination}

Many researchers $[22,23]$ investigated the possibility of capturing silica even before the dissolution or dissolved silicon in solution by the addition of lime in order to form dicalcium silicates, as shown in Eq. 12.

$2 \mathrm{CaO}_{(\mathrm{s})}+\mathrm{SiO}_{2(\mathrm{~s})} \rightleftharpoons \mathrm{Ca}_{2} \mathrm{SiO}_{4(\mathrm{~s})}$

Due to the reaction mechanism, the molar ratio $\mathrm{CaO} /$ $\mathrm{SiO}_{2}(\mathrm{C} / \mathrm{S})$ becomes a distinctive parameter to describe this process. Following reaction 12 , the optimum ratio $\mathrm{C} / \mathrm{S}$ should be in the range of 2. Cresswell's [22, 24] highpressure caustic leaching experiments confirm this assumption and he reports increasing aluminum recoveries with increasing ratio $\mathrm{C} / \mathrm{S}$ up to 2 . But the aluminum recovery declines again at higher lime additions due to the formation of hardly or even insoluble calcium aluminates. Nevertheless, it needs to be emphasized that the actually needed amount of lime may vary due to the composition of the input material and the conditions during the digestion. It is necessary to bond the "reactive" silica. Depending on the mineralogy and process temperature, not the entire silica content is mobilized by the leach liquor and thus lower lime additions may be suitable as well.

Lime is also used to bond titania, which occurs in bauxite mostly as rutile and anatase, in more thermodynamically stable phases like perovskite [25]. This can be an important issue, since $\mathrm{Gu}$ et al. [26] found that anatase affects the aluminum recovery from diaspore negatively. The addition of calcium compounds and the transformation of anatase into perovskite reduce the concentration of titanite ions in the liquor and avoid the retardation effect of anatase in bauxite.

In order to improve the aluminum recoveries in the sinter process, besides lime even more expensive divalent alkaline metals like barium oxide or magnesia are used and play an important role in some studies [27]. Here again silica is transformed into insoluble compounds following Eq. 13 by the release of sodium oxide. This reaction can also occur directly in the presence of quartz as described in Eq. 14.

$$
\begin{aligned}
& \mathrm{Na}_{2} \mathrm{SiO}_{3(\mathrm{~s})}+2 \mathrm{AO}_{(\mathrm{s})} \rightleftharpoons \mathrm{A}_{2} \mathrm{SiO}_{4(\mathrm{~s})}+\mathrm{Na}_{2} \mathrm{O}_{(\mathrm{s})} \\
& \mathrm{A}=\text { divalent alkaline metals } \\
& \mathrm{SiO}_{2(\mathrm{~s})}+2 \mathrm{AO}_{(\mathrm{s})} \rightleftharpoons \mathrm{A}_{2} \mathrm{SiO}_{4(\mathrm{~s})}
\end{aligned}
$$


Soda losses due to the reaction with titania can also be avoided by reaction 15 and sodium ferrite will partly react in the presence of alkaline metal oxides with a concurrent release of sodium oxide, as shown in Eq. 16. [15, 25, 27-29]

$$
\begin{aligned}
& \mathrm{Na}_{2} \mathrm{TiO}_{3(\mathrm{~s})}+\mathrm{AO}_{(\mathrm{s})} \rightleftharpoons \mathrm{ATiO}_{3(\mathrm{~s})}+\mathrm{Na}_{2} \mathrm{O}_{(\mathrm{s})} \\
& 2 \mathrm{NaFeO}_{2(\mathrm{~s})}+2 \mathrm{AO}_{(\mathrm{s})} \rightleftharpoons \mathrm{A}_{2} \mathrm{Fe}_{2} \mathrm{O}_{5(\mathrm{~s})}+\mathrm{Na}_{2} \mathrm{O}_{(\mathrm{s})}
\end{aligned}
$$

The sinter process in the presence of sufficient divalent alkaline metals A (according to Meher and Pahdi [27, 28]) forms all the products shown in the reactions 4-6 and 12-16. All chemical reactions in the subsequent leaching process with water are summarized in Eq. 17 and create an aluminum containing caustic solution and an insoluble slurry.

$$
\begin{aligned}
& \mathrm{NaAlO}_{2(\mathrm{~s})}+\mathrm{A}_{2} \mathrm{SiO}_{4(\mathrm{~s})}+2 \mathrm{NaFeO}_{2(\mathrm{~s})}+\mathrm{A}_{2} \mathrm{Fe}_{2} \mathrm{O}_{5(\mathrm{~s})} \\
& \quad+\mathrm{ATiO}_{3(\mathrm{~s})}+3 \mathrm{H}_{2} \mathrm{O}_{(\mathrm{l})} \rightleftharpoons \\
& \mathrm{NaAl}(\mathrm{OH})_{4(\mathrm{aq})}+2 \mathrm{NaOH}_{(\mathrm{aq})}+\mathrm{A}_{2} \mathrm{SiO}_{4(\mathrm{~s})}+\mathrm{Fe}_{2} \mathrm{O}_{3(\mathrm{~s})} \\
& \quad+\mathrm{A}_{2} \mathrm{Fe}_{2} \mathrm{O}_{5(\mathrm{~s})}+\mathrm{ATiO}_{3(\mathrm{~s})}
\end{aligned}
$$

\section{Experimental}

Red mud from the landfill in Lünen, Germany is used in all experiments. The former VAW (Vereinigte Aluminium Werke) operated an alumina plant from 1939 to
1987. The deposited red mud varies through the decades in its composition due to different bauxite suppliers and bauxite deposits. For test trials, one batch is homogenized and analyzed by x-ray fluorescence (XRF) for chemical composition and by $\mathrm{x}$-ray diffraction (XRD) for phase analysis. The results are shown in Table 1 and indicate that the aluminum extraction in former times was inefficient and therefore the remaining aluminum amount of $27 \mathrm{wt} \%$ is comparably high. The $\mathrm{x}$-ray diffractogram in Fig. 1 reveals that the predominant phase is hematite. Only a small amount of iron can be detected as goethite. Aluminum even after the Bayer process is mostly present as gibbsite, to lower extend as boehmite and in traces as diaspore. High amounts of aluminum are bonded in sodalite, and albite is only apparent in traces. Titanium is detectable as anatase and rutile.

In addition to this red mud, the chemicals used for the experiments are concentrated sodium hydroxide solution (technical purity 48-50\%), lime (powder, commercial purity $95 \% \mathrm{CaO}, 1.4 \% \mathrm{SiO}_{2}, 1.2 \% \mathrm{MgO}$ ), sodium carbonate (anhydrous powder $>99.5 \%$ ), and lignite coke $(88 \% \mathrm{C})$.

The processes employed are described in detail in the following sections. An overview for comparison purposes and better understanding is given in Fig. 2 .
Table 1 Chemical composition of used materials and yielded metal phase after reductive smelting
Fig. 1 X-ray diffractogram (Mo-K $\alpha_{1}$-radiation $0.70930 \AA$ ) of used red mud

\begin{tabular}{lllllllll}
\hline Component in wt\% & $\mathrm{Fe}_{2} \mathrm{O}_{3}$ & $\mathrm{Al}_{2} \mathrm{O}_{3}$ & $\mathrm{SiO}_{2}$ & $\mathrm{CaO}$ & $\mathrm{Na}_{2} \mathrm{O}$ & $\mathrm{TiO}_{2}$ & $\mathrm{Cr}_{2} \mathrm{O}_{3}$ & $\mathrm{C} / \mathrm{S}$ \\
\hline Red mud, Lünen (dried) & 28.5 & 27 & 13.1 & 3.8 & 7 & 8 & 0.35 & 0.3 \\
Alumina-enriched slag & $1.18^{2}$ & 39.9 & 18.4 & 29.1 & 2,79 & $11^{2}$ & 0.07 & 1.7 \\
\hline Component in wt\% & $\mathrm{Fe}$ & $\mathrm{C}$ & $\mathrm{Cr}$ & $\mathrm{Si}$ & $\mathrm{Ti}$ & $\mathrm{P}$ & $\mathrm{S}$ \\
\hline Metal phase from red mud smelting & 92.4 & 5 & 0.95 & 0.13 & 0.7 & 0.33 & 0.01 \\
\hline $\begin{array}{l}\text { 1 Original moisture 31 \% } \\
\text { Predominantly metallic (iron), or sub oxides, but calculated as } \mathrm{Fe}_{2} \mathrm{O}_{3}, \mathrm{TiO}_{2} \text {, respectively }\end{array}$
\end{tabular}

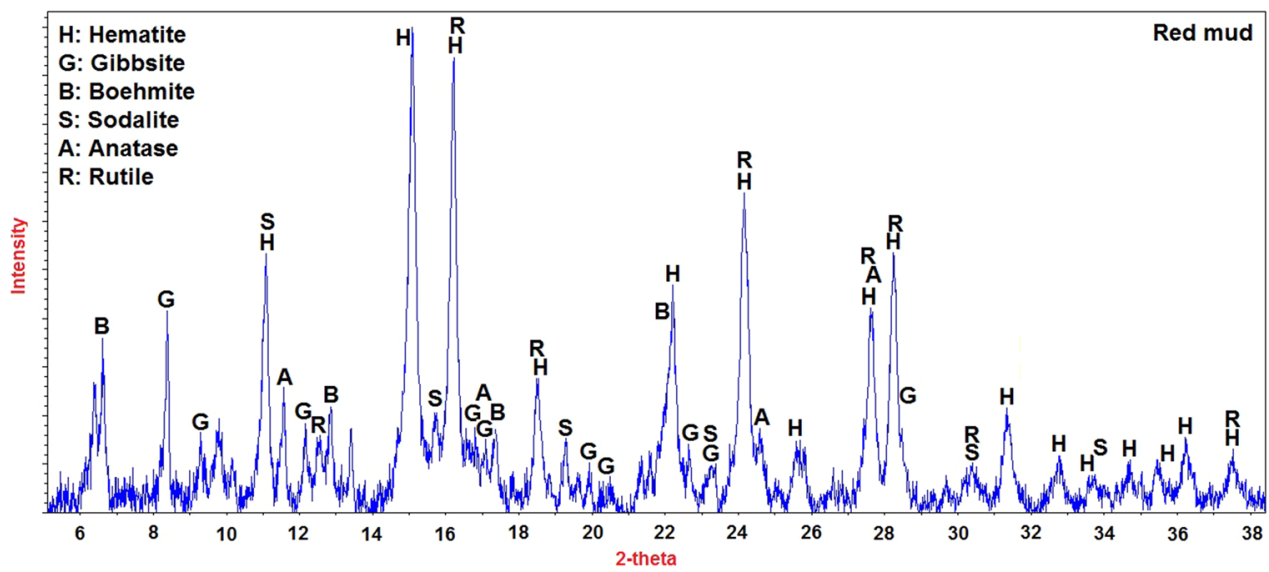


Fig. 2 Flowchart of the experimental compared processes for aluminum recovery from red mud

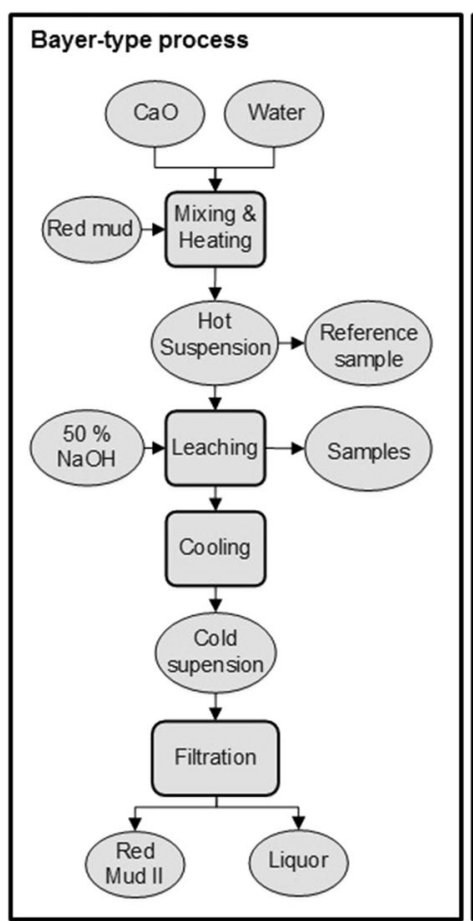

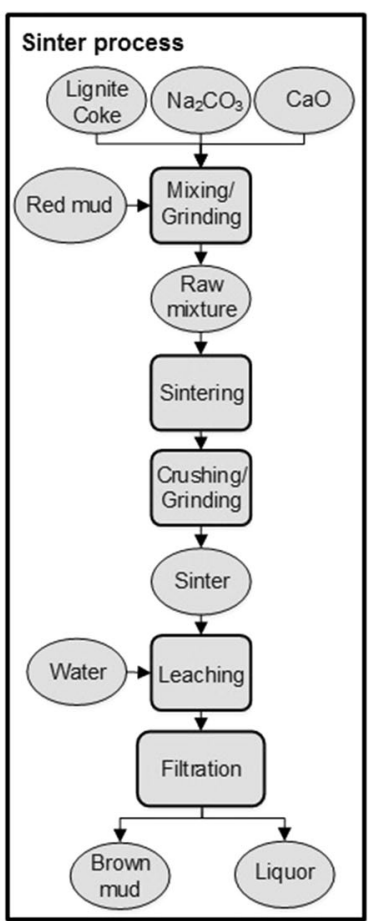

\section{Bayer Process}

All experiments are conducted in a 21 autoclave. For best corrosion resistance, the leach suspension is kept in a titanium vessel inside the stainless steel pressure cylinder. The titanium vessel limits the operating volume to 11 . An agitator avoids settling of the suspension and a cooling helix cools the suspension rapidly down after the experiment or in case of exothermic reactions to keep the process temperature on the preset level. An immersion tube enables taking samples during the experiment. The pressure inside the autoclave presses a sample volume inside a watercooled sample cylinder which quenches the sample within seconds from process temperature down to $50{ }^{\circ} \mathrm{C}$. The temperature is measured by a type $\mathrm{K}$ thermocouple which is immersed in the suspension and controls the heating jacket outside the pressure cylinder. Agitator, thermocouple sheath, and immersion tube for sampling and cooling helix are made of titanium. Liquid reagents (weak acids, caustic solutions) can be added during the experiment by an external feeding system made up of stainless steel (Fig. 3).

In every experiment, $147 \mathrm{~g}$ dry material consisting of red mud with composition shown in Table 1 and if applicable lime are mixed together with 590-730 ml water (depending on the sodium hydroxide concentration in the experiment) to form a suspension. Under constant agitation, the suspension is heated up for approx. $150 \mathrm{~min}$ to $270-280{ }^{\circ} \mathrm{C}$. Thereafter, the first sample $(7 \mathrm{~g}$ material and
$30 \mathrm{ml}$ solution) is taken, and by the subsequent addition of concentrated sodium hydroxide the desired solid-to-liquid ratio of 1:6 $(140 \mathrm{~g}: 850 \mathrm{ml})$ is created. Due to the liquid feed, the temperature drops to $220^{\circ} \mathrm{C}$ and reaches $250{ }^{\circ} \mathrm{C}$ process temperature within $10-15 \mathrm{~min}$. The process temperature is kept for $120 \mathrm{~min}$, while frequent samples track the course of reaction. At the end, the suspension is cooled for $30 \mathrm{~min}$ and the leach residue is separated from the liquor by vacuum filtration.

\section{Bayer Process with Alumina-Enriched Slag}

In order to change the mineralogy of the input material and reduce the hematite completely to metallic iron, overall $5000 \mathrm{~g}$ red mud is smelted with $1200 \mathrm{~g}$ lime and $500 \mathrm{~g}$ lignite coke as reduction agents in two batches in an electric arc furnace (direct current setup with water-cooled bottom electrode and graphite top electrode), as shown in Fig. 2. After preheating of the furnace, the material is continuously fed in the graphite crucible. To ensure the complete reduction of the entire hematite content, carbon is supplied in excess by lignite coke and the graphite crucible. Moreover, after the input material was completely smelted, a holding time of $1 \mathrm{~h}$ at temperatures in the range of 1650 $1700{ }^{\circ} \mathrm{C}$ was kept to finish the reduction. Due to the high amount of alumina (see Table 1), the liquidus temperature of the slag phase is increased and requires process temperature of $>1600^{\circ} \mathrm{C}$ for a stable process with a fluid slag. After smelting, the entire melt is then poured into a steel 
Fig. 3 Sketch of used autoclave and electric arc furnace
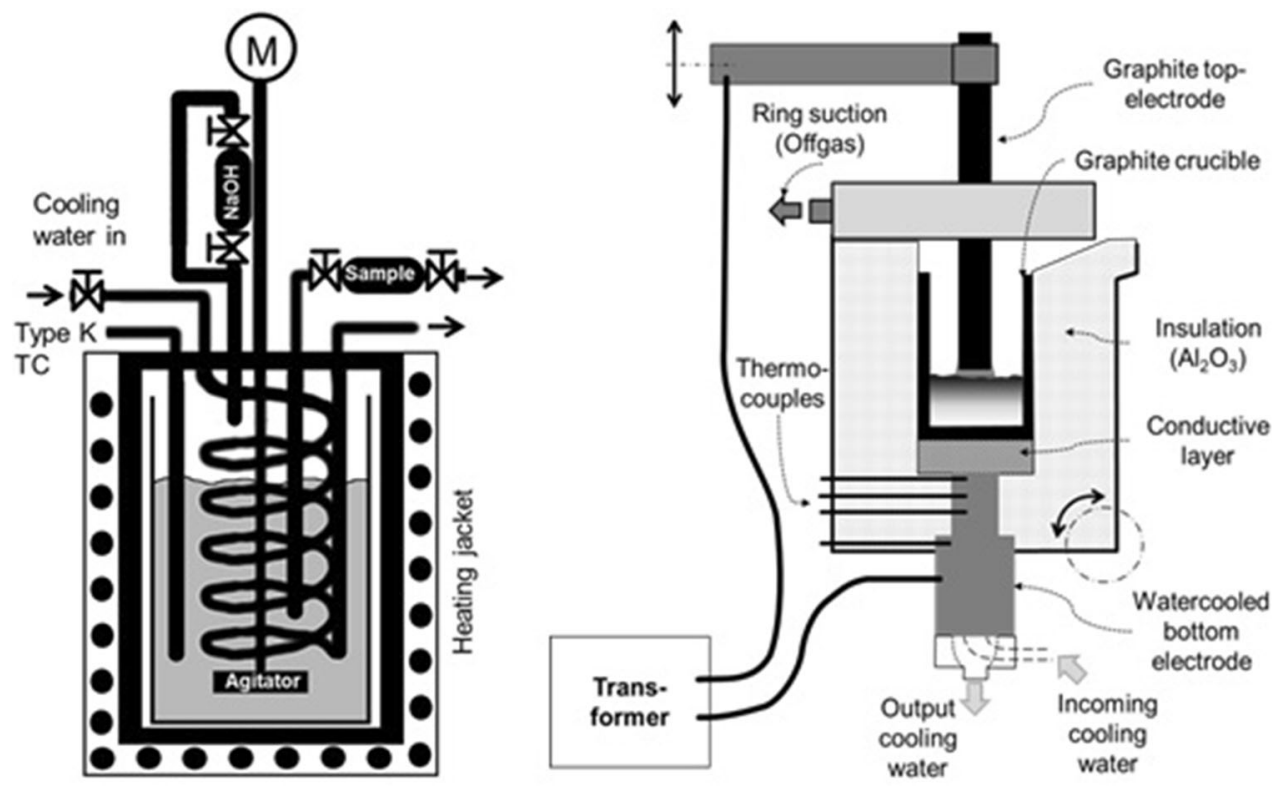

mold in which the formed pig iron phase is separated from the slag phase by settling. The chemical composition of used materials and yielded metal phase after reductive smelting are shown in Table 1. Apparently the metal phase can be described as typical pig iron, which is carbon saturated, rich in phosphor and has to be further treated and refined in a converter to produce steel [30]. For further processing, the slag phase is crushed and ground to grain size $<125 \mu \mathrm{m}$, and entrapped metal droplets are removed by magnetic separation. It can be seen from the composition shown in Table 1 that enough lime is added to transform the entire titania content into calcium titanate (perovskite) and to offer sufficient lime to form calcium silicates. The XRD analysis in Fig. 4 reveals that the transformation of titania to perovskite occurs completely but no stoichiometric calcium silicate phases are detectable. The only silica containing detected phase is dicalcium dialuminum silicate trioxide. Thus, it is liable that calcium silicates are present in the slag phase but as mixed phases with varying $\mathrm{C} / \mathrm{S}$ stoichiometries or as amorphous phase.

In each trial, $50 \mathrm{~g}$ of ground slag are mixed with $500 \mathrm{ml}$ sodium hydroxide solution of varying $\mathrm{NaOH}$ concentrations, and the suspension is filled in the titania vessel of the above-mentioned 21 autoclave. The heating process to test temperatures of 170,200 , and $250{ }^{\circ} \mathrm{C}$ takes approximately 90-150 min and the subsequent holding period at process temperature lasts $180 \mathrm{~min}$. Afterward, the suspension is cooled down within $30 \mathrm{~min}$ to $50{ }^{\circ} \mathrm{C}$ and the residue is separated from the liquor by vacuum filtration.

\section{Sinter Process}

For sinter preparation, the mixture of $100 \mathrm{~g}$ red mud and various amounts of sodium carbonate, lime, and lignite coke are intensively mixed and ground in a disk mill. The raw mixture is sintered in a $280 \mathrm{ml}$ fire clay crucible at
Fig. 4 X-ray diffractogram $\left(\mathrm{Cu}-\mathrm{K} \alpha_{1}\right.$-radiation $\left.1.54059 \AA\right)$ of alumina-enriched slag after carbothermic reduction of red mud $(\mathrm{Cu}$ radiation)

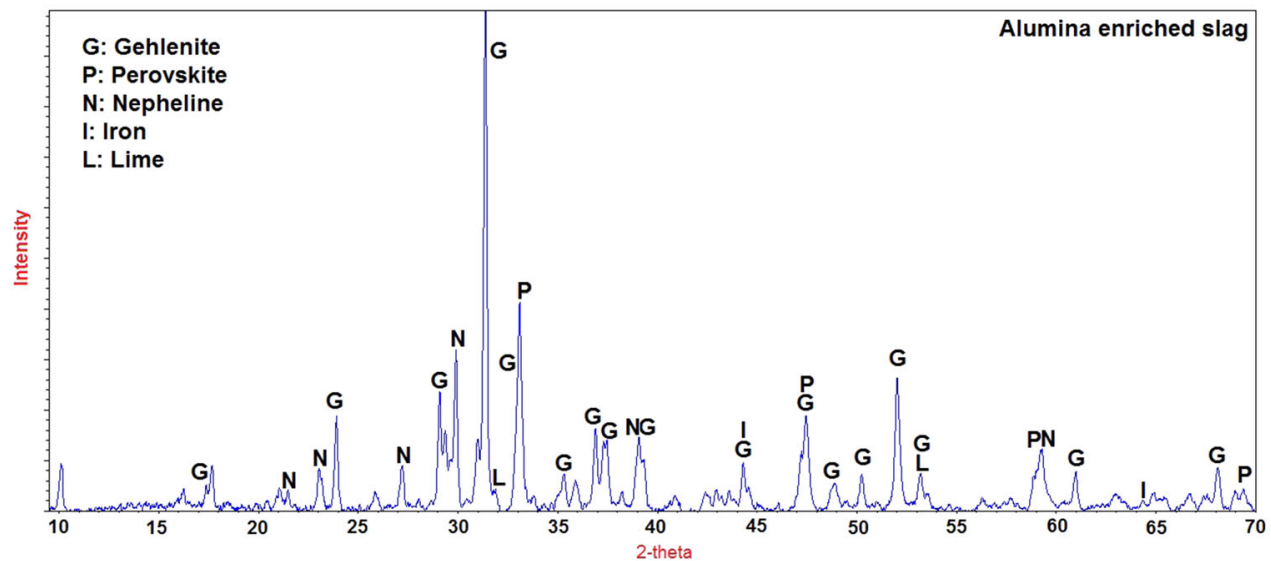


different temperatures. A type $\mathrm{K}$ thermocouple inside the bulk material monitors the heating process and ensures that the mixture is held at process temperature for least $90 \mathrm{~min}$ to establish the chemical equilibrium state. After cooling, the sinter is crushed and milled again for the subsequent leaching step with $640 \mathrm{ml}$ water at $50{ }^{\circ} \mathrm{C}$ for $30 \mathrm{~min}$. The leaching residue is afterward separated from the liquor by vacuum filtration.

\section{Analytics}

The samples of slag, sinter, and leach residues are analyzed by XRF (model: PANanlytical Axios) and XRD (model: Stoe\&Cie STADI P with Cu-Ka1-radiation $1.54059 \AA$, $40 \mathrm{kV}, 30 \mathrm{~mA}$ for low iron-containing samples and Stoe\&Cie STADI MP with Mo-Ka1-radiation $0.70930 \AA$, $55 \mathrm{kV}, 35 \mathrm{~mA}$ for high iron-containing samples). For crosschecking purpose also the leaching solutions are analyzed by inductively coupled plasma optical emission spectrometry (model: Spectro ICP-OES Spectro Flame D). Therefore, the aluminum concentration in the liquor is kept below the solubility limit, which is ensured by the high solid-to-liquid ratios of $1 / 6$ in case of Bayer process with bauxite residue and sintering and 1/10 in case of aluminaenriched slag leaching.

\section{Results and Discussion}

The assumption that the treated red mud still contains digestible aluminum phases (gibbsite and boehmite according to XRD) from which aluminum can be mobilized is verified throughout all series of trials. First of all, the influence of leaching temperature is examined by keeping the sodium hydroxide concentration at $200 \mathrm{~g} / \mathrm{l}$, without any lime addition. It can be seen from Fig. 5 that the aluminum recovery can be improved from $48 \%$ at $150{ }^{\circ} \mathrm{C}$ to $53 \%$ at $250{ }^{\circ} \mathrm{C}$ according to the analysis of the residue after the filtration and verified by the ICP analysis from the solution. The highest temperature of $250{ }^{\circ} \mathrm{C}$ is then chosen with different sodium hydroxide concentrations varying from 100 up to $300 \mathrm{~g} / \mathrm{l}$. The results are shown in Fig. 5 as well. Even a low concentration of $100 \mathrm{~g} / \mathrm{l}$, $\mathrm{NaOH}$ extracts more than $50 \%$ of the aluminum content. Following the ICP results, the aluminum recovery drops at higher $\mathrm{NaOH}$ contents and is contradictory to the XRF analysis of the leaching residue which shows a slightly increasing aluminum yield at higher $\mathrm{NaOH}$ concentrations.

The comparably high extraction efficiencies at a low $\mathrm{NaOH}$ concentration of $100 \mathrm{~g} / \mathrm{l}$ and even at a low temperature of $150{ }^{\circ} \mathrm{C}$ can be explained by the ongoing weathering and aging process inside the landfill. Although the bauxite residue has been washed and pre-neutralized after Bayer process, the remaining moisture has a $\mathrm{pH}$ value of 10-12 and seems to disintegrate the minerals through the period of 20-70 years. It is expected that aluminum recoveries increase with increasing sodium hydroxide content and aggressiveness of the leach liquor. But strong sodium hydroxide solutions even dissolve silica compounds and lead to an increased concentration of dissolved silicon which is shown in the diagrams of Fig. 5 as well. The formation and precipitation of sodium aluminum silicates result and lower the aluminum concentration and thus the aluminum recovery. This effect becomes obvious by comparing the course of aluminum recovery with the silicon concentration in the liquor during the leaching, exemplarily as shown in Fig. 6 for experiments with increasing sodium hydroxide concentration from 100 to $300 \mathrm{~g} / \mathrm{l}$. At $100 \mathrm{~g} / \mathrm{l} \mathrm{NaOH}$, the leaching is completed after $60 \mathrm{~min}$, and the concentrations of aluminum and silicon stay at the same level. At $200 \mathrm{~g} / \mathrm{l}$, the leaching is completed after $30 \mathrm{~min}$ and aluminum and silicon concentrations decrease simultaneously with ongoing leaching time. At $300 \mathrm{~g} / \mathrm{l} \mathrm{NaOH}$, the leaching is completed within 10 15 min. With increasing leaching time, mainly silicon dissolves, while aluminum dissolves only very slowly and an equilibrium of newly dissolved ions and firstly precipitated sodium aluminum silicates is reached. After $60 \mathrm{~min}$,
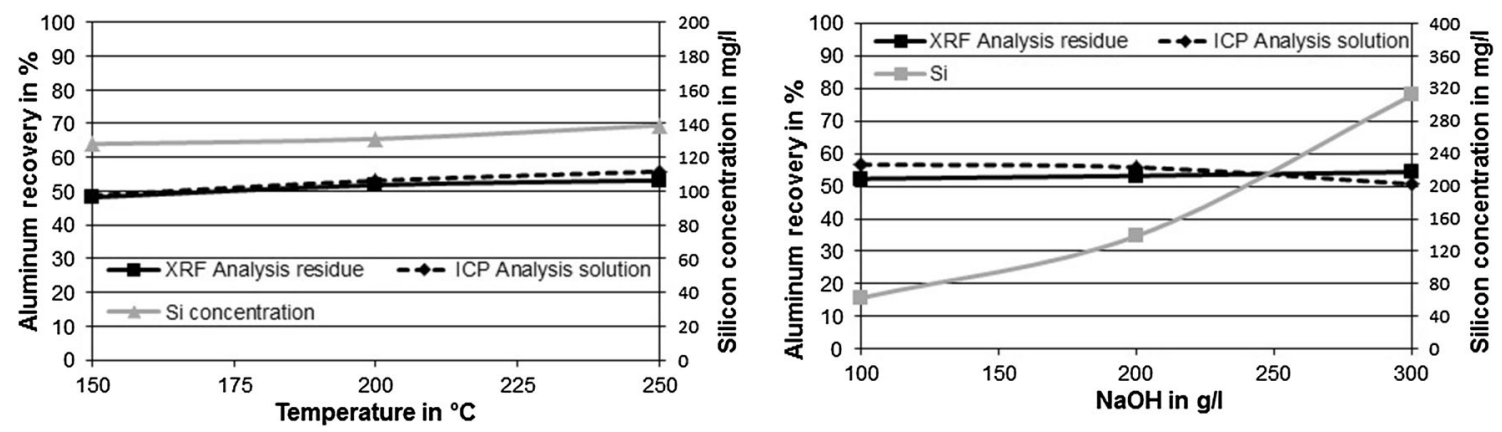

Fig. 5 Effect of temperature and $\mathrm{NaOH}$ concentration on aluminum recovery from red mud in Bayer process after 120-min leaching at process temperature 

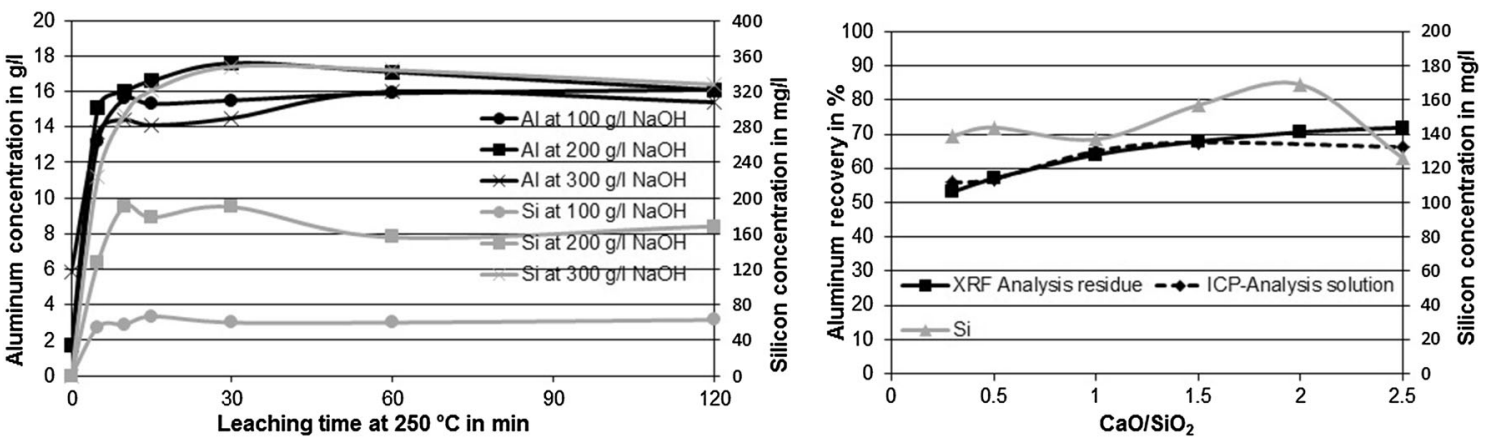

Fig. 6 (Left) Kinetics of aluminum and silicon dissolution at $250{ }^{\circ} \mathrm{C}$, without lime addition $(\mathrm{C} / \mathrm{S}=0.3)$, solid/liquid ratio of $1: 6$ and various $\mathrm{NaOH}$ concentrations. (Right) Effect of lime addition on aluminum

the precipitation of sodium aluminum silicates becomes dominant and decreases both aluminum and silicon concentrations in the leachate.

The best way to avoid simultaneous dissolution of silica is leaching at low sodium hydroxide concentrations. Increasing the sodium hydroxide concentration from 100 to $300 \mathrm{~g} / 1$ increases the dissolved silicon concentration by the factor of five from $60 \mathrm{mg} / \mathrm{l}$ to more than $300 \mathrm{mg} / \mathrm{l}$. Therefore, the sodium hydroxide concentration is kept at $200 \mathrm{~g} / \mathrm{l}$ and the addition of lime is examined by varying the $\mathrm{C} / \mathrm{S}$ from 0.3 (initial red mud) to 2.5 , as shown in Fig. 6. By increasing $\mathrm{C} / \mathrm{S}$ to $1-1.5$, the aluminum recovery can be significantly improved from 55 to $68 \%$. Further addition of lime has only little advantages on the extraction of aluminum, increasing the recovery from 68 to $72 \%$ by raising $\mathrm{C} / \mathrm{S}$ from 1.5 to 2.5 . The silicon concentration in the leach liquor remains at the same level between 120 and $170 \mathrm{mg} / \mathrm{l}$.

XRD patterns of leached red mud confirm that aluminum hydroxides (gibbsite and boehmite) are completely leached out. The remaining aluminum-containing phases are sodium aluminum silicates like albite, sodalite, and especially cancrinite and in traces diaspore. Anatase has turned into rutile, and the characteristic hematite peaks dominate the diffractogram. But the first phase transformations occur even during heating to process temperature with water. At $250{ }^{\circ} \mathrm{C}$, only small amounts of boehmite are detectable and the predominant aluminum hydroxide is diaspore, which can even be proved after $120 \mathrm{~min}$ of leaching at $250{ }^{\circ} \mathrm{C}$ with $200 \mathrm{~g} / 1 \mathrm{NaOH}$. Lime addition makes the mineralogy more complex and besides hematite and cancrinite, katoite and zoisite are formed. Moreover, several other calcium silicates like alite, wollastonite, and combeite capture silica and allow higher aluminum extractions.

The changed mineralogy of smelted red mud slag affects the leaching behavior, and the aluminum recoveries are shown in Fig. 7. Calcium aluminates are more difficult to dissolve than gibbsite or boehmite and as a consequence recovery from red mud in Bayer process after 120-min leaching at $250{ }^{\circ} \mathrm{C}$, solid/liquid ratio of $1: 6$ and $200 \mathrm{~g} / 1 \mathrm{NaOH}$

the aluminum recoveries at $200 \mathrm{~g} / 1 \mathrm{NaOH}$ are below $50 \%$. At $300 \mathrm{~g} / \mathrm{l} \mathrm{NaOH}$, the alumina extraction is comparable with the results from the red mud leaching. Cracking the strong calcium aluminate compounds requires higher digestion temperatures. Below $250{ }^{\circ} \mathrm{C}$, even high sodium hydroxide concentrations are not able to mobilize the aluminum and the recoveries are in the range of $60 \%$. But with increasing temperature, aluminum recoveries $>90 \%$ can be achieved at elevated sodium hydroxide concentrations of $>500 \mathrm{~g} / \mathrm{l}$.

Generally, the silicon concentration during slag leaching is slightly higher than measured in the experiments with red mud even at lower leaching temperatures and low sodium hydroxide concentrations. This indicates that the silica minerals in slag are more reactive than quartz compounds in original red mud. With increasing sodium hydroxide concentration, the silicon content in the leachate increases simultaneously, and especially at sodium hydroxide concentrations $>572 \mathrm{~g} / \mathrm{l}$, the silicon concentration rises exponentially up to values of $4 \mathrm{~g} / \mathrm{l}$ and more. But in contrast to the leaching behavior of red mud, the aluminum concentration in the leachate increases continuously during the experiment, while the silicon concentration continuously decreases which allows higher aluminum recoveries with longer leaching durations.

The leaching residue has been analyzed by XRD and reveals the aluminum entrapments as undissolved calcium aluminate, gehlenite, and small amounts of grossular. Wellknown minerals from the Bayer process, sodalite, and cancrinite do not appear, but due to the high lime addition the entire titania content is transformed into perovskite. It is noticeable that the alumina content in slag can be reduced from $40 \mathrm{wt} \%$ to values in the range of $2-4 \mathrm{wt} \%$ meaning an aluminum recovery of up to $95 \%$.

Comparable to the reductive smelting of red mud, the chemical and phase compositions of bauxite residue are completely changed by the dry digestion with sodium carbonate and the addition of lime and coke, respectively. 


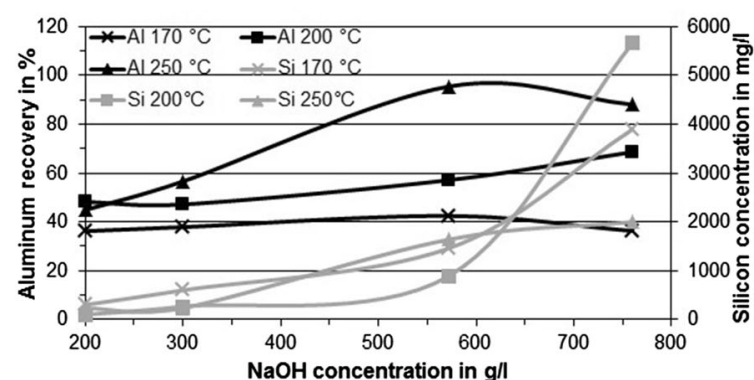

Fig. 7 Bayer process of alumina-enriched slag: Effect of $\mathrm{NaOH}$ concentration and temperature (left) and leaching time (right) on aluminum recovery and silicon concentration in solution after

As a result, many different phases occur which are very difficult to distinguish. Most abundant are disodium calcium silicate $\left(\mathrm{Na}_{2} \mathrm{CaSiO}_{4}\right)$, calcio-olivine $\left(\mathrm{Ca}_{2} \mathrm{SiO}_{4}\right)$, $\mathrm{CaSi}_{2} \mathrm{O}_{5}$, and perovskite $\left(\mathrm{CaTiO}_{3}\right)$. It was not possible to detect iron-containing phases clearly. Only in the case of coke addition, strong $\alpha$-iron peaks prove the presence of iron. Aluminum can be detected as calcium aluminates $\left(\mathrm{Ca}_{3} \mathrm{Al}_{2} \mathrm{O}_{6}, \mathrm{Ca}_{4} \mathrm{Al}_{6} \mathrm{O}_{13}\right)$, albite $\left(\mathrm{NaAlSi}_{3} \mathrm{O}_{8}\right)$, plazolite $\left(\mathrm{Ca}_{3} \mathrm{Al}_{2} \mathrm{Si}_{2} \mathrm{O}_{12}\right)$, and combeite $\left(\mathrm{Na}_{4.5} \mathrm{Ca}_{3.5} \mathrm{Si}_{6} \mathrm{O}_{18}\right)$.

The first series of trials examined the best process temperature for sintering regarding the highest aluminum recovery in the subsequent leaching with water. It can be seen from Fig. 8 that the alumina recovery generally increases with increasing sintering temperature up to the solidus temperature of the mixture. Two series with sufficient sodium carbonate addition of $60 \%$ regarding the mass of used red mud and different lime additions (without lime and with $15 \%$ lime addition) resulting in a C/S of 0.3 and 1.5 , respectively, are conducted. The courses of the recovery graphs show that lime addition positively affects the aluminum yield at lower sintering temperatures below $800{ }^{\circ} \mathrm{C}$. At higher temperatures, red mud/sodium carbonate mixtures without lime show higher aluminum recoveries

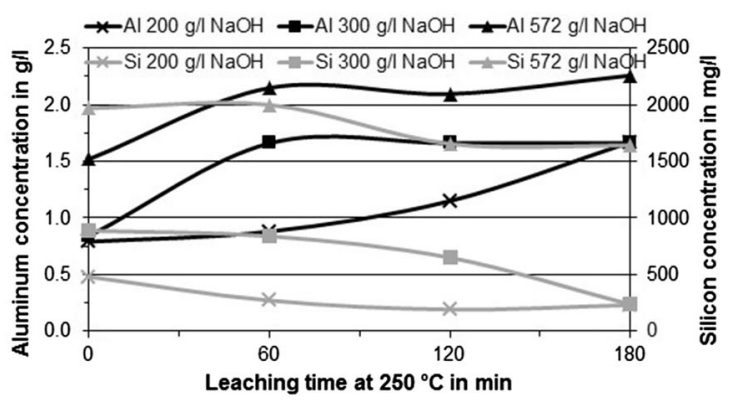

180-min leaching time and solid/liquid ratio of 1:10 (left) and (right) kinetics of aluminum and silicon dissolution at $250{ }^{\circ} \mathrm{C}$, solid/liquid ratio of 1:6 and various $\mathrm{NaOH}$ concentrations

compared to mixtures with a high $\mathrm{C} / \mathrm{S}$ of 1.5 . The latter reach almost the same alumina extraction of about $80 \%$ but at higher sintering temperatures of almost $1100{ }^{\circ} \mathrm{C}$ in contrast to pure red mud/ $\mathrm{Na}_{2} \mathrm{CO}_{3}$ mixtures which show the same recoveries even below $1000{ }^{\circ} \mathrm{C}$.

At elevated temperatures above $800{ }^{\circ} \mathrm{C}$, a third series with reduced sodium carbonate addition of $28 \%$ (regarding red mud mass) slightly reduced $\mathrm{C} / \mathrm{S}$ of 1.3 , and stoichiometric $\left(\mathrm{Fe}_{2} \mathrm{O}_{3} \rightarrow \mathrm{Fe}\right)$ coke addition of $8 \%$ has been conducted. Up to $900{ }^{\circ} \mathrm{C}$, this mixture allows comparable aluminum recoveries which decline at higher temperatures. A forth series with over stoichiometric coke addition of sufficient sodium carbonate content $(60 \%)$ yields generally higher aluminum recoveries at lower sintering temperatures.

The effect of sodium carbonate addition is examined at $1000{ }^{\circ} \mathrm{C}$ sintering temperature and $\mathrm{C} / \mathrm{S}$ of 1.5 . According to reactions 4 and 6 , the calculated necessary sodium carbonate addition for stoichiometric transformation of $\mathrm{Fe}_{2} \mathrm{O}_{3}$, $\mathrm{Al}_{2} \mathrm{O}_{3}, \mathrm{TiO}_{2}$, and $\mathrm{SiO}_{2}$ into their sodium compounds is $70 \%$ regarding the red mud mass input. As shown in Fig. 8, the sodium carbonate addition was raised from 16 up to $80 \%$ and demonstrates that the highest aluminum
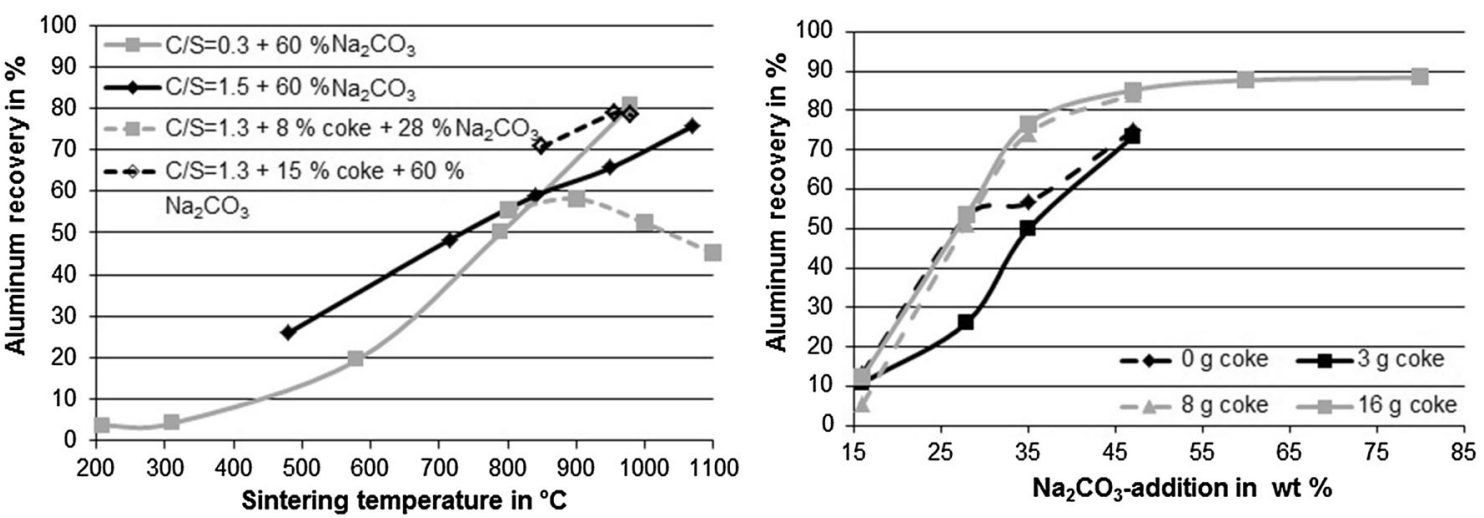

Fig. 8 Red mud sintering: Aluminum recovery depending on the sintering temperature $(l e f t)$ and depending on the sodium carbonate addition and lignite coke addition in the sintering stage at $1000{ }^{\circ} \mathrm{C}$ and $\mathrm{C} / \mathrm{S}$ of 1.3 
recovery of $88 \%$ cannot be reached below this stoichiometric necessary amount of $70 \%$ sodium carbonate addition. On the contrary, the extraction rate approximates asymptotically to this maximum, so that the aluminum recovery of $80 \%$ at approximately $40 \%$ sodium carbonate addition can only be increased by 10 to $88 \%$ by doubling the sodium carbonate addition.

The effect of coke addition is also shown in Fig. 8. All trials are done at $1000{ }^{\circ} \mathrm{C}$ with $\mathrm{C} / \mathrm{S}$ of 1.3 . Coke additions of $3 \%$ (double stoichiometric regarding $\mathrm{Fe}_{2} \mathrm{O}_{3} \rightarrow \mathrm{Fe}_{3} \mathrm{O}_{4}$ ), $8 \%$ (stoichiometric $\mathrm{Fe}_{2} \mathrm{O}_{3} \rightarrow \mathrm{Fe}$ ), and $16 \%$ (twice the stoichiometric $\mathrm{Fe}_{2} \mathrm{O}_{3} \rightarrow \mathrm{Fe}$ ) are compared with the aluminum recovery of experiments without coke addition. It becomes obvious that the addition of only $3 \%$ coke lowers the aluminum extraction even below the mixtures without coke addition at sodium carbonate additions below $50 \%$. In addition, the other coke additions of $8 \%$ and $16 \%$ do not improve the aluminum extraction below $30 \% \mathrm{Na}_{2} \mathrm{CO}_{3}$ addition. An improvement in aluminum yield takes place by adding more than $35 \% \mathrm{Na}_{2} \mathrm{CO}_{3}$. Then, the addition of $8 \%$ coke increases the recovery by $10-15 \%$ to values of $77 \%\left(35 \% \mathrm{Na}_{2} \mathrm{CO}_{3}\right)$ and $85 \%\left(48 \% \mathrm{Na}_{2} \mathrm{CO}_{3}\right)$ compared to 57 and $74 \%$, respectively, without coke addition. A further increase of coke addition does not improve the aluminum recovery at all.

A study varying the $\mathrm{C} / \mathrm{S}$ ratio from 0.3 (native red mud) to 1.5 is examined in two series of experiments at 910 and $1040{ }^{\circ} \mathrm{C}$. It is clearly shown in Fig. 9 that the aluminum recovery increases with increasing $\mathrm{C} / \mathrm{S}$ up to 1.1. Thereafter, the recovery decreases slightly. The higher sintering temperature further improves the aluminum yield only at $\mathrm{C} / \mathrm{S}$ above 0.8 and it becomes obvious that the responsible chemical reactions at higher $\mathrm{C} / \mathrm{S}$ need higher temperatures of $>950{ }^{\circ} \mathrm{C}$ to take place. Figure 9 also shows the silicon concentration in the leachate. According to reaction 12, the silicon can be successfully bonded by higher lime activities

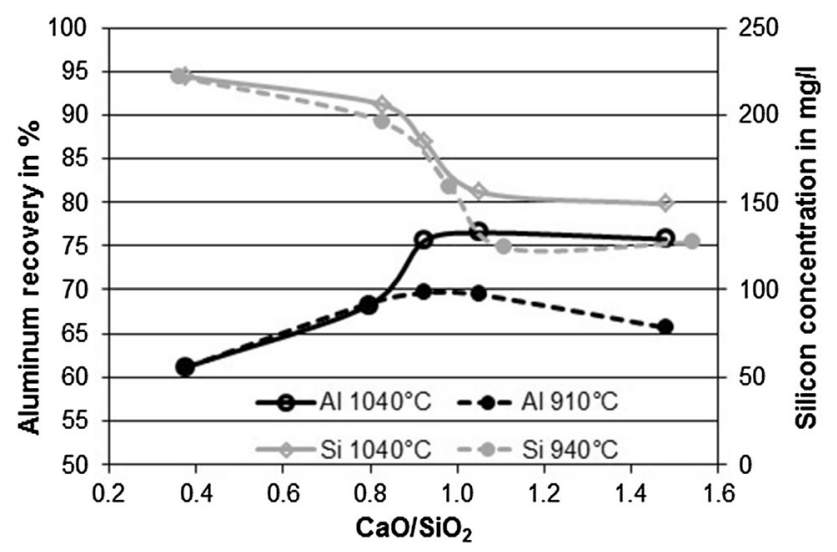

Fig. 9 Effect of lime addition on aluminum recovery at $910{ }^{\circ} \mathrm{C}$ and $1040{ }^{\circ} \mathrm{C}$ sintering temperature with $60 \% \mathrm{Na}_{2} \mathrm{CO}_{3}$ addition in the system and this thesis is confirmed by the results from the experiments. The ratio $\mathrm{C} / \mathrm{S}$ of 0.8 seems to be critical due to the used red mud composition. At higher $\mathrm{C} / \mathrm{S}$ values from 0.8 to 1.1 , the concentration of dissolved silicon drops by $25 \%$ at sintering temperature of $1040{ }^{\circ} \mathrm{C}$, by $50 \%$ at $910{ }^{\circ} \mathrm{C}$, respectively. Above $\mathrm{C} / \mathrm{S}$ of 1.1 , the effect of lime becomes negligible.

The results from leaching experiments of the sintered material can be explained by XRD analysis. At higher lime additions, the calcium activity increases and compounds like albite $\left(\mathrm{NaAlSi}_{3} \mathrm{O}_{8}\right)$, plazolite $\left(\mathrm{Ca}_{3} \mathrm{Al}_{2} \mathrm{Si}_{2} \mathrm{O}_{12}\right)$, and combeite $\left(\mathrm{Na}_{4.5} \mathrm{Ca}_{3.5} \mathrm{Si}_{6} \mathrm{O}_{18}\right)$ are formed which reduce the amount of soluble silicon and thus the silicon concentration in the leachate. The liberated aluminum reacts to sodium aluminate which is water-soluble and increases the aluminum recovery. The temperature dependency observed in Fig. 9 is difficult to explain because at lower temperatures the diffractograms show more amorphous phases but especially the formation of calcio-olivine seems to be preferred at higher temperatures and can be an explanation for higher aluminum recoveries at higher sintering temperatures.

\section{Conclusions}

Bauxite residues from legacy sites and from former times may still contain leachable amounts of aluminum compounds like gibbsite, boehmite, or diaspore. It has been shown in experiments that these amounts can be easily extracted using the Bayer process once again. Even mild conditions like low temperatures of $150{ }^{\circ} \mathrm{C}$ at $200 \mathrm{~g} / \mathrm{l}$ $\mathrm{NaOH}$ or low $\mathrm{NaOH}$ concentrations of $100 \mathrm{~g} / \mathrm{l}$ in combination with $250{ }^{\circ} \mathrm{C}$ process temperature can extract almost half of the aluminum content. With the optimized parameters, i.e., higher temperatures than $250{ }^{\circ} \mathrm{C}$, higher concentrations than $200 \mathrm{~g} / \mathrm{l} \mathrm{NaOH}$ and lime addition to a $\mathrm{C} / \mathrm{S}$ of 1.5 (for better recoveries even $\mathrm{C} / \mathrm{S}$ up to 2.5 are possible, but it has to be proven if higher lime additions are economical reasonable) up to $70 \%$ of the aluminum content can be recovered without the simultaneous leaching of silica. The remaining aluminum losses are connected with the formation of sodalite and cancrinite. The use of higher concentrations of sodium hydroxide solutions predominantly results in a higher silicon contamination of the liquor without considerable benefits on the extraction of aluminum.

Reductive smelting of bauxite residue with lime addition as flux and silicon binder will create a slag phase with considerably high alumina contents of approximately $40 \mathrm{wt}$ $\%$ and completely changed mineralogy compared to the original red mud. The extraction of aluminum from calcium aluminate slags requires especially high-digestion 
temperatures of $250{ }^{\circ} \mathrm{C}$ and more. Moreover, higher sodium hydroxide concentrations of $>500 \mathrm{~g} / \mathrm{l}$ can be used to extract almost the entire aluminum content and afterward the leaching residue contains less than $3 \mathrm{wt} \% \quad \mathrm{Al}_{2} \mathrm{O}_{3}$ bonded in compounds like remaining calcium aluminate and gehlenite. But generally, these drastic conditions of elevated process temperatures and high sodium hydroxide concentrations mean an increased wear of equipment and result in very high concentrations of dissolved silicon in the leachate $(2 \mathrm{~g} / \mathrm{l})$ with corresponding effects on quality and purity of the crystallized aluminum hydroxide. Furthermore, the solubility limit of aluminum in caustic liquor increased with increasing sodium hydroxide concentrations and it becomes difficult to reach the aluminum saturation necessary for a crystallization of aluminum hydroxide.

The best combination of high aluminum recoveries and low silicon concentrations in the leachate is achieved with the sodium carbonate sinter process. To achieve aluminum recoveries above $70 \%$, the sintering temperature should be above $900{ }^{\circ} \mathrm{C}$ and the sodium carbonate addition should be at least $35 \%$ regarding the mass of treated red mud. The addition of lime up to a $\mathrm{C} / \mathrm{S}$ of 1.1 improves the aluminum extraction, lowers the silicon concentration in the leachate, and assures later on a crystallized aluminum hydroxide product of comparable purity to the Bayer process. Moreover, the addition of coke in order to reduce the hematite to metallic iron improves the aluminum recovery further. Therefore, with best parameters of $60 \% \mathrm{Na}_{2} \mathrm{CO}_{3}$ addition, $\mathrm{C} / \mathrm{S}$ of 1.1 , stoichiometric coke addition for a complete hematite reduction ( $8 \%$ regarding mass of red mud), and 1000-1050 ${ }^{\circ} \mathrm{C}$ sintering temperature, almost $90 \%$ of the aluminum content in red mud can be recovered. Moreover, the sodium hydroxide concentration in the leachate compared to Bayer process is very low and simplifies the winning of aluminum hydroxide in the subsequent crystallization step.

Surely the sintering process is very cost intensive due to its high process temperature and the need of high sodium carbonate additions. The sodium containing spent liquor must be further treated, for instance, by vaporization, in order to recover and recycle sodium. Yet, this process offers exceptional recovery rates within expected short process times and an aluminum hydroxide product of high purity. The use of coke and the solid reduction of hematite to metallic iron which can be separated by magnetic separation create a salable by-product which might improve the financial viability of the process.

Although these processes have yet been proven for high aluminum-containing bauxite residues from legacy sites, after increased efficiency and reduced processing cost, they might be even practical for fresh bauxite residues.
Acknowledgments The project upon which this publication is based is funded by the German Federal Ministry of Education and Research (BMBF) under project number 033R085A. This publication reflects the views of the authors only. Special thanks to the School of Mining \& Metallurgical Engineering, National Technical University of Athens for practical support in the slag leaching experiments.

\section{References}

1. Arpe H-J, Ullmann F (1985) Ullmann's encyclopedia of industrial chemistry. Wiley, Weinheim

2. Barin I (1995) Thermochemical data of pure substances. VCH Verlagsgesellschaft mbH, Weinheim

3. Haynes WM (2016) CRC handbook of chemistry and physics. CRC Press, Boca Raton

4. International Aluminium Institute (2014) Bauxite residue management: best practice. http://aluminium.org.au/_literature_ 175772/Bauxite_Residue_Management_-_Best_Practice_\%28IAI\% 29. Accessed 10 April 2015

5. Paramguru RK, Rath PC, Misra VN (2005) Trends in red mud utilization: a review. Miner Process Extr Met 26:1-29

6. Authier-Martin M, Forté G, Ostap S, See J (2001) The mineralogy of bauxite for producing smelter-grade alumina. JOM 53 (12):36-40

7. Duncan A, Muller-Steinhagen H, Verity B, Welch B (1995) An investigation of desilication kinetics in spent bayer liquor. In: Evans JW (ed) Light metals 1995. TMS, Warrendale, PA, pp 37-44

8. Reyes CAR, Williams C, Alarcón OMC (2013) Nucleation and growth process of sodalite and cancrinite from kaolinite-rich clay under low-temperature hydrothermal conditions. Mater Res 16:424438

9. Barnes MC, Addai-Mensah J, Gerson AR (1999) The kinetics of desilication of synthetic spent Bayer liquor seeded with cancrinite and cancrinite: sodalite mixed-phase crystals. J Cryst Growth 200:251-264

10. Barnes MC, Addai-Mensah J, Gerson AR (1999) The mechanism of the sodalite-to-cancrinite phase transformation in synthetic spent Bayer liquor. Microporous Mesoporous Mater 31:287-302

11. Barnes MC, Addai-Mensah J, Gerson AR, Smart RC (1999) The solubility of sodalite and cancrinite in synthetic spent liquor and the mechanism and kinetics of the sodalite to cancrinite phase transformation. In: Eckert CE (ed) Light metals 1999. TMS, Warrendale, PA, pp 131-140

12. Liu Z, Li H (2015) Metallurgical process for valuable elements recovery from red mud: a review. Hydrometallurgy 155:29-43

13. Alp A, Selim Gora M (2003) The effects of the additives, calcination and leach conditions for alumina production from red mud. Scand J Metall 32:301-305

14. Hrishikesan (1975) US 4,045,537

15. Kamlet J (1960) US 2,964,383

16. Li X-B, Xiao W, Liu W, Liu G-H, Peng Z-H, Zhou Q-S, Qi T-G (2009) Recovery of alumina and ferric oxide from Bayer red mud rich in iron by reduction sintering. Trans Nonferr Metal Soc 19:1342-1347

17. Raghavan P, Kshatriya NK, Wawrynink K (2011) Recovery of Metal values from Red Mud. In: Lindsay S (ed) Light metals 2011. TMS, Warrendale, PA, pp 103-106

18. Jander G, Blasius E, Strähle J, Schweda E, Rossi R (2006) Jander-Blasius lehrbuch der analytischen und präparativen anorganischen Chemie. Hirzel

19. Rich RL (2007) Inorganic reactions in water. Springer, Berlin

20. Xenidis A, Zografidis C, Kotsis I, Boufounos D (2009) Reductive roasting and magnetic separation of greek bauxite residue for its 
utiliazation in iron ore industry. In: Crepeau PN (ed) Light metals 2009. TMS, Warrendale, PA, pp 63-67

21. Yao Z, Xia M, Sarker P, Chen T (2014) A review of the alumina recovery from coal fly ash, with a focus in China. Fuel 120:74-85

22. Cresswell P, Milne D (1982) A hydrothermal process for recovery of soda and alumina from red mud. In: Anderson JA (ed) Light metals 1982. TMS, Warrendale, PA, pp 227-238

23. Lindsay SJ (2011) The study on the reaction of rutile in Bayer liquor. In: Lindsay S (ed) Light metals 2011. TMS, Warrendale, PA, pp 43-48

24. Cresswell et al. (1984) US 4,483,830

25. Bi S, Li D, Yang Y, Fu G, Xin Z, Li Y (1996) The study on the reaction of rutile in Bayer liqour. In: Hale W (ed) Light metals 1996. TMS, Warrendale, PA, pp 43-48

26. Gu S-Q, Yin Z-L, Zhou H-F (1993) Behaviour of some additives in bayer digestion process of diasporic bauxite. In: Das SK (ed) Light metals 1993. TMS, Warrendale, PA, pp 27-33
27. Meher S Narayan, Padhi B (2014) A novel method for extraction of alumina from red mud by divalent alkaline earth metal oxide and soda ash sinter process. Int $\mathbf{J}$ Environ Waste Manag 3 (13):231-245

28. Narayan Meher S, Rout AK, Padhi B (2010) Extraction of Al and $\mathrm{Na}$ from red mud by magnesium. Afr J Environ Sci Technol 4 (13):897-902

29. Tathavadkar V, Antony MP, Jha A (2002) Improved extraction of aluminium oxide from bauxite and redmud. In: Schneider W (ed) Light metals 2002. TMS, Warrendale, PA, pp 199-203

30. Kaußen F, Friedrich B (2015) Reductive smelting of red mud for iron recovery. Chem Ing Tech 87:1535-1542 